\title{
Political theory and the agony of politics
}

Andrew Schaap, Department of Political Science, The University of Melbourne, Victoria 3010 Australia aschaap@unimelb.edu.au

Books reviewed:

Chantal Mouffe, On The Political (Milton Park: Routledge, 2005).

Michael Walzer. Politics and Passion: Towards a More Egalitarian Liberalism (New Haven \& London: Yale University Press, 2005).

Hannah Arendt. The Promise of Politics, edited by Jerome Kohn (New York: Schocken Books, 2005).

...the criteria of the political...is the friend/enemy discrimination. It deals with the formation of a ' $w e^{\prime}$ as opposed to a 'they' and is always concerned with collective forms of identification; it has to do with conflict and antagonism and is therefore the realm of decision, not free discussion.

(Mouffe 2005, 11)

What is crucial for us here is to understand freedom itself as political and not as a purpose...to be obtained by political means, and to realise that coercion and brute force are always a means for protecting or establishing or expanding political space, but in and of themselves are definitely not political.

(Arendt 2005, 130)

In a 1990 article in Political Theory, Michael Walzer wrote that, like the fashion for pleated trousers in the 1980s, the communitarian critique of liberalism is transient but certain to return. ${ }^{1}$ Walzer attributes the transience of communitarianism to the fact that it cannot provide an alternative to liberalism but only a corrective to certain problematic tendencies within it toward instability, disassociation and depoliticisation. Liberals are now widely understood to have won the debate with their communitarian critics of the 1980s due to liberalism's accommodation of communitarian concerns within autonomy-based theories such as Will Kymlicka's

\footnotetext{
${ }^{1}$ The article is reprinted as an appendix to Politics and Passion.
} 
(1989). However, what Walzer calls 'standard liberalism' did not emerge from this controversy unchanged. Rather, in challenging liberalism's bifurcation and privileging of morality over ethics, reason over history and, generally, philosophy over politics, the communitarian critique succeeded in pushing liberalism in a more political direction. This was apparent in the development of John Rawls' (1993) work and in the shift of interest among political theorists from justice to democracy and from rights to deliberation in the 1990 s. $^{2}$

The importance of each author reviewed here for contemporary political theory is in continuing the critique of liberal political theory in its current dialogical manifestation. The turn to dialogue in liberal theory provides the basis of its claim to have developed a more democratic political philosophy in contrast to its earlier monological approach. The work of Mouffe, Arendt and Walzer, however, draws attention to what is elided in the contemporary representation of legitimate politics as dialogue and, thereby, to liberalism's continuing disavowal of its own political exclusions. If the discourse of rights favoured by liberals in the 1980 s tended to overlook the moral and political significance of social interdependence, what the discourse of deliberation tends to neglect is the moral and political significance of contest and struggle which, following the Greeks, is increasingly referred to in contemporary political theory as 'agonism'.

In this review article, I draw out the commonalities and differences among these three agonistic critics of liberalism according to three inter-related themes: the meaning of politics and the nature of 'the political', the significance of conflict and passion in political life, and the constitution of political community. In doing so, I suggest that, like the communitarian critique of liberalism, the

\footnotetext{
${ }^{2}$ I am grateful to Keith Breen, Bonnie Honig, George Vasilev and two anonymous readers for their comments on the first draft of this review.
} 
current agonistic critique of dialogical liberalism is likely to be transient but certain to return. The transience of the agonistic critique, however, is not due to its dependence on the liberal paradigm. Rather it arises from a difficulty inherent in praxis philosophy itself: the problem of conceptualising political action independently of its institutional representation, which leads Sheldon Wolin (1996), for instance, to characterise democracy as 'fugitive'.

There is a parallel difficulty between the challenge of radical political action and its philosophical articulation. At the political level, the challenge is how to stage resistance to the current hegemonic order in a way that does not reinforce the institutions it seeks to overthrow; at the philosophical level, the challenge is to articulate a critique that resists being appropriated as a further development of the ideology it interrogates. In this context, to describe the current preoccupation with agonism in contemporary political theory as a corrective to dialogical liberalism would be to surrender too much. ${ }^{3}$ For, as Bonnie Honig observes ${ }^{4}$, 'the corrective view is a liberal strategy - it is how liberalism treats all its critics, and that is why it is hegemonic'.

\section{The ethical-political significance of dissensus}

All three books reviewed here are centrally concerned with political conflict and attribute to it a certain ethical significance. Each book also provides a restatement and elaboration of ideas first published in the 1990s during which the agonistic critique of liberalism superceded the communitarian one. Walzer's intention in writing Politics and Passion was to elaborate on the communitarian

\footnotetext{
${ }^{3}$ I am indebted to Bonnie Honig for counselling against such surrender in her comments on an earlier version of this paper.

${ }^{4}$ Personal correspondence, 22 March 2006.
} 
'correction' of liberalism that he referred to in his 1990 article. In developing this critique, Walzer examines several aspects of political life that liberalism fails to properly attend to: involuntary association, collective powerlessness, the problems posed by cultural marginality, the hierarchies of civil society, the politics of social conflict and the force of passionate engagement. These exclusions, he argues, 'make the struggle against inequality more difficult than it ought to be' (xi). More difficult because they leave unacknowledged the extent to which the struggle against inequality is constitutive of what it is to be just in an imperfect world.

Liberal philosophy typically takes as its starting point the ideal of a society of free and equal citizens and works back from there to critique or justify existing political arrangements and practices. But in doing so it misses the significance of the experience of injustice and the struggle for equality for the constitution of political community and the enjoyment of democratic freedom. An agonistic approach, in contrast, takes the 'rough ground' (Wittgenstein) of struggles over recognition as its starting point for thinking about what justice requires (see also Honneth 1995; Wolin 1996a; Mouffe 2000; Tully 2004).

Mouffe's latest book provides a concise and lucid restatement of the main ideas first presented in her influential 1993 collection of essays The Return of the Political. In On the Political Mouffe advances two simple but plausible claims: that politics always has a 'partisan' element and 'for people to be interested in politics they need to have the possibility of choosing between parties offering real alternatives' (p.29). Against the prevailing neo-liberal consensus, the importance of an adversarial contest between parties on the Left and Right of politics is to make these alternatives available. Mouffe's conceptualisation of 'the political', outlined in the second chapter, provides the basis from which she intervenes in 
several recent debates in political theory concerning the 'third way', risk society, deliberative democracy, cosmopolitanism, right-wing populism and terrorism.

Although Arendt died in 1975, her work was prominent in debates in political theory in the 1990s. The opening chapter of the Promise of Politics was previously published in Social Research in 1990 as 'Philosophy and Politics.' The remaining chapters, which contain several of Arendt's other previously unpublished writings from the 1950s, similarly circle around the issue that unites Arendt's corpus: the relation between thought and action and the problem of 'thinking what we are doing'.

Most of the ideas expressed in the book are more fully developed in Arendt's major works. However, the main essay in the collection ('Introduction into Politics') illuminates these other texts and provides some important insights into Arendt's agonism. ${ }^{5}$ If the importance of political conflict for Walzer is that it is fundamental to the realisation of social equality and for Mouffe that it makes available meaningful choices that could engage the demos in political life, what becomes clear on reading this book is that for Arendt, it is, in revealing the social world from a plurality of perspectives, political conflict has the potential to disclose the commonness of that world to conflicting parties.

\section{The non-deliberative setting of deliberative politics}

In Politics and Passion, Michael Walzer insists that democratic politics entails more than deliberation: 'opposition and conflict, disagreement and struggle where the stakes are high - that's what

\footnotetext{
${ }^{5}$ Arendt's agonism has been emphasized by authors such as Bonnie Honig (1993) and Dana Villa (1996) against her appropriation for a dialogical politics by Habermasians such as Seyla Benhabib (1996) and Maurizio Passerin d'Entreves (1993).
} 
politics is' (117). ${ }^{6}$ Walzer argues that while deliberation is an important aspect of democracy, there are many non-deliberative activities that democratic politics legitimately involves, of which he identifies fourteen: political education, organization, mobilisation, demonstration, statement, debate, bargaining, lobbying, campaigning, voting, fund-raising, corruption, scutt-work and ruling (92-102). What these non-deliberative activities have in common is that they are oriented to success rather than understanding: they are strategic rather than communicative forms of action (to use Habermas's terms) or work rather than action (to use Arendt's terms).

Against dialogical liberalism, Walzer argues that politics is less about what decision to favour than what group to join. While deliberative democracy is able to recognise most of Walzer's nondeliberative practices as legitimate democratic activities, it does so in a way that subordinates them to consensus-oriented public reasoning. In the dialogical model, for instance, voting and bargaining are permitted where consensus cannot be achieved due to what Rawls calls the burdens of judgment (limited time, imperfect knowledge of the social world and so on). However, consensus nonetheless continues to function as a regulative ideal since the outcome of voting or bargaining will be more legitimate to the extent that it is preceded by a deliberation in which the particular interests of all those affected by a decision are represented in relation to an anticipated normative consensus, even though such consensus is rarely, in fact, arrived at.

For Walzer, however, what dialogical liberalism fails to recognise is the extent to which 'deliberation's proper place is

\footnotetext{
${ }^{6}$ My characterisation of Walzer as an agonist might be surprising given his usual association with communitarianism. However, Walzer has long been preoccupied with developing a fullblooded political theory of politics. Think, for instance, of his work on 'dirty hands' and his republican valorisation of politics more generally (Walzer 1973, 1981).
} 
dependent on activities that it doesn't constitute or control' (107). In other words, non-deliberative politics set the scene for the staging of public reason. Walzer's agonistic critique of dialogical liberalism here parallels his communitarian critique of the representation of liberal society as a voluntary association. Reason is always exercised within a political context just as free choice is only possible in the context of 'involuntary association' or socialisation (18). Like its rights-based precursor, dialogical liberalism 'retains a certain bias for the courtroom' in that it tends to represent democratic decision-making on the model of reaching a verdict $(91,103)$. Yet political life differs from the courtroom in that it is not possible to assume that there is one single just outcome available. Rather, settlements reached through politics are always potentially contestable precisely because 'different interests and ideological commitments are often irreconcilable' (103).

Walzer's recent turn to thinking about the ethical significance of passion and dissensus for realising social democracy is an interesting and important development of his work. Yet, as the recent work of Stuart Hampshire (2000) and Cass Sunstein (2003) demonstrates, the account of the non-deliberative politics that he provides can be accommodated within dialogical liberalism, albeit in a somewhat emaciated form. As Adrian Little (2004) discusses, while Hampshire and Sunstein have made admirable attempts at recognising the importance of conflict for thinking about liberal justice, they have done so in a way that continues to privilege the institutional setting of conflict. As such, political conflict is only conditionally accommodated within a liberal framework by domesticating it in relation to the meta-political standards of public reason. ${ }^{7}$ With this move, political action that would fundamentally challenge the terms of political association either appears

\footnotetext{
${ }^{7}$ For a sustained critique of Sunstein and the republican legal theorists' argument about the constitutional 'containment' of dialogical politics see Christodoulidis (2006).
} 
unreasonable or does not register as meaningful at all (see also Shiffman 2002; Brady 2004).

Walzer fails to fundamentally challenge this capacity of liberalism to co-opt political conflict into the service of a normative order that it would otherwise call into question because he does not adequately distinguish between the non-deliberative activities he describes (politics) and their representation in terms of an ideal consensus (the political). Walzer's point about the non-deliberative setting of deliberative politics has potentially wide-reaching and devastating consequences for dialogical liberalism, which typically inverts this relation in terms of the deliberative (consensusoriented) setting of non-deliberative (dissensual) politics. Radicalising Walzer's critique requires that we show what is occluded in representing the non-deliberative in terms of the deliberative: that setting here amounts to programming and therefore to the foreclosure of political opportunity. But to understand this, we need to draw the distinction between politics and the political that is central to the agonistic critique of liberalism.

\section{Politics and 'the political'}

In moving beyond Walzer's pertinent but somewhat mild critique of liberalism, theorists of agonistic politics today are presented with a choice between Arendt and Schmitt. Whereas Arendt and the republican tradition views political life in terms of its horizontal dimension of freedom, solidarity and collective action, Schmitt and the realist tradition emphasises the vertical dimension of necessity, rule and sovereignty (see Ricoeur 1965). Consequently, republicans (such as Arendt, Walzer, Tully and Lefort) view political conflict as having a potentially world-disclosing or integrative function. In contrast, realists (such as Schmitt, Mouffe, Derrida and Agamben) 
understand political conflict as always tending toward a relation of exclusion.

While in both traditions 'the political' refers to an extraordinary moment of politics - the constitution of a "we" - each tradition views this constituency as being delimited in a different way. While for Arendt the political refers to the experience of solidarity in moments of collective action, for Schmitt the political refers to the emergence of the friend-enemy relation. In both traditions, the anticipation of 'the political' as an ever-present possibility conditions ordinary politics: the potential intensification of politics toward violent confrontation on the one hand or the potential disclosure of a common world to those engaged in political action on the other.

Neither Arendt nor Walzer distinguish between politics and the political. However this distinction is increasingly drawn in contemporary political theory and it is one on which Mouffe explicitly relies. According to Mouffe, whereas political science inquires into the facts of politics with its manifold practices and conflicts, political theory is concerned with the political, which refers to the 'way in which society is instituted' (9), the symbolic unity in terms of which conflict is represented as social. As such, political theory is fundamentally concerned with those universal concepts such as human rights and popular sovereignty in relation to which a society reflexively constitutes its self.

'The political' is understood to be autonomous in the sense that the terms in which social conflict is represented are seen to be (at least potentially) a product of self-conscious human activity or politics. While politics is not everything (there is no control centre from which society might be governed), everything is political (because the terms in which society is ordered are contingent they are contestable) (Mouffe 2005: 17-18; see also Christodoulidis 1998: 254). Politics brings the contingency of the social order into 
view; in revealing that society could be otherwise it reveals the social order as artifice, as product of human action and therefore open to change.

The concept of the political in this way fulfils an analogous task in agonistic theories of politics to that which consensus performs in deliberative theories: it provides something like a quasitranscendental principle or counterfactual image of sociality in terms of which to understand ordinary politics. The key difference is that, for agonists, 'the political' cannot function as a regulative idea in the same way that consensus is supposed to in dialogical theories. In dialogical theories, the regulative idea of consensus is typically invoked as a meta-political principle that determines in advance the terms of political association and of what counts as reasonable or unreasonable, legitimate or illegitimate political action and speech. In contrast, agonistic theories emphasise that what counts as reasonable or unreasonable is itself always a political question since politics ultimately concerns the background of social meaning against which conflict is enacted, the representation of the "we" that authorises political institutions and actions. ${ }^{8}$

\section{Exclusion and enmity: the Schmittian conception of the political}

Drawing on Carl Schmitt, Mouffe defines the political as 'the dimension of antagonism which...is constitutive of human societies' (9). Following Schmitt, the political refers to the potential for violent

\footnotetext{
${ }^{8}$ As Bert van Roermund $(1997,158)$ explains, while both approaches refer to a 'transcendence from within', for theorists of agonistic democracy 'the transcendence in question is not a necessary and universal (though counterfactual) presupposition of established communication, but a regional, though necessary presupposition to establish communication (or, for that matter, socialisation). Exclusion seems to be at the heart of communication. Those who 'we' appear not to understand, the barbarians as the ancient Greeks called them, are rather those we have chosen not to understand in the first place. Communication as based on exclusion is something which has to be philosophically accounted for, especially in a philosophy of law.'
} 
confrontation between enemies. A disagreement or conflict becomes political as it intensifies toward violence or war. Importantly, the concept of the political does not refer to the violent encounter between enemies as such but to the intensification in which the distinction between friend and enemy is meaningful. The political is said to be autonomous (e.g. of economics, morality, etc.) in that its guiding distinction is independent of other criteria such as the moral distinction between right and wrong or the juridical distinction between legal and illegal (Schmitt 1996, 26-27). That is to say, although political questions and issues are often represented in terms of these other antitheses - and arise from disagreements about what is right, beautiful, useful, etc. - the guiding political distinction between friend and enemy is not reducible to them and cannot ultimately be decided by recourse to other non-political value-criteria.

The most important insight of Schmitt, according to Mouffe, is that in demonstrating that 'every consensus is based on acts of exclusion' he reveals 'the impossibility of a fully inclusive 'rational' consensus' (11). In other words, the anticipated moral consensus in terms of which free and equal citizens are supposed to represent their particular claims, according to dialogical liberalism, is always also politically constituted and therefore potentially ideological. In fact, politics always ultimately concerns the representation of public reason, which delineates the terms in which deliberation is carried out by providing criteria for distinguishing the reasonable from the unreasonable. For Mouffe, the starting point for an adequate democratic theory therefore must be acknowledgement of the antagonistic dimension of politics since this brings the political nature of the terms of political discourse back into view.

As distinct from the 'the political', Mouffe takes politics to refer to 'the set of practices and institutions through which an order is 
created, organising human coexistence in the context of conflictuality provided by the political' (9). Whereas the political refers to the potential emergence of antagonism, politics refers to the agonistic struggle for hegemony. Drawing on her earlier work with Ernesto Laclau, Mouffe appropriates the notion of hegemony from Antonio Gramsci, which refers to the dominant ideas that legitimate a social order. In contrast to the orthodox Marxist conception of ideology, these dominant ideas do not simply serve the interests of the dominant class by legitimating the economic organization of society. Rather, cultural hegemony actively constitutes social interests, identities and relations of power. Every society, Mouffe argues, 'is the product of a series of practices attempting to establish order in a context of contingency' (p. 17). Mouffe refers to this struggle for hegemony as 'agonism': the symbolic contest over the constitution of society, the institution of an order in which a potentially inter-communal conflict (war) is represented as communal (politics).

In thinking 'with Schmitt against Schmitt' Mouffe wants to understand how the us/them distinction might work within the polity (e.g. in terms of Left and Right-wing political parties) to constitute plurality rather than viewing plurality as a necessary threat to the preservation of the political association or evidence of its decline. When formulated this way, the challenge for democracy no longer appears as how to overcome the we/they opposition (as Mouffe imputes to liberalism). Rather the problem is how to draw the distinction in a way that is 'compatible with the recognition of the pluralism which is constitutive of modern democracy' (14). In other words, the challenge for democracy is to accommodate dissensus without either assimilating it within the terms of an anticipated moral (liberal) consensus (Habermas) or denying its legitimacy in the name of political unity (Schmitt). 
Given Schmitt's collaboration with the Nazi regime, however, it is reasonable to wonder whether it is possible to appropriate Schmitt for a radical theory of democracy as Mouffe wants to or whether, rather, it is necessary to 'think against' Schmitt from within a different set of presuppositions and guiding concerns (but see Kalyvas 2000). There are at least two grounds on which the Schmittian conception of the political appears inadequate to the task. First, at the empirical level, it seems doubtful whether every political identity is necessarily constituted in contrast to an antagonist. While this certainly is often the case, it is similarly plausible that an identity might sometimes emerge reflexively out of cooperation or conflict that is shared by those who are party to it, for example, through a struggle for recognition. Second, and related to this, Mouffe's hope to employ the Schmittian conception of the political in a way that is compatible with plurality appears problematic unless it can account for the emergence of more than two perspectives out of a conflict that is initially dichotomous. But this seems implausible to the extent that a relation of friendship is based an identification formed in opposition to a hostile other. While the Schmittian conception of the political is important for bringing the politics of liberalism back into view, the Arendtian conception of the political provides a more adequate starting point if we are to understand plurality as potentially constitutive of political commonality.

\section{Freedom and world-disclosure: the Arendtian conception of the political}

While Arendt does not distinguish politics from the political, some contemporary political theorists who are influenced by her do (e.g. Wolin 1983; Lefort 1988). Moreover, employing this distinction helps to make sense of Arendt's understanding of the 'meaning of 
politics' as outlined in her 'Introduction Into Politics', which otherwise seems anachronistic and idiosyncratic given her reliance on Greek and Roman sources. To take some interpretive license: if, for Arendt, politics arises from the fact of human plurality (93), the political refers to the disclosure of commonality from this plurality through public interaction.

In contrast to the tradition of philosophy, which takes 'man' in the singular (e.g. the rights-holding individual of liberal thought) to be the subject of politics, Arendt argues that a genuinely political theory would start from wonder at the plurality of men and women who inhabit the social world. Moreover, what it should attempt to understand is 'the political': the disclosure of the world that 'lies between men', which results from public action and speech. As such, political theory should be primarily concerned not with the ends that political action might serve or the goals to which it might be oriented but the principles that animate it. Following Montesquieu, Arendt understands the principles of political action (such honour, virtue and fear but also fame, freedom, justice and equality) to refer to the 'fundamental conviction that a group of people share' (195).

In this context, Arendt insists that the meaning of politics is freedom (108). Yet, she observes, this classical understanding of politics seems to be contradicted by the experience of totalitarianism and the threat of nuclear war. Whereas the politicisation of all aspects of life under totalitarianism confirms the liberal prejudice that freedom begins where politics ends, the development of the atomic bomb leads to the hope that politics might be dispensed with entirely before it destroys all life on earth. Both experiences deprive liberal theory of its instrumental justification of politics: if politics is only a necessary evil for protecting life and yet politics itself constitutes the greatest threat 
to human life in modernity, then modern politics is indeed in danger of being meaningless (110).

Yet, Arendt argues, the widespread sense of the meaningless of politics is actually a consequence of our modern prejudices against politics, which she aims to dispel by exposing their historical contingency (152-153). The first prejudice that obscures our view of politics is that it is a universal aspect of the human condition that comes about wherever people live together. For the Greeks, on the contrary, politics exists only where there is a polis, a space within which people who have liberated themselves from the necessities of life are free to inter-act with their equals without compulsion, force or rule. When understood in these terms politics is by no means a necessity but in fact 'has existed so rarely and in so few places that, historically speaking, only a few great epochs have known it and turned it into a reality' (119). ${ }^{9}$

The second prejudice that obscures our view of politics is that it can be meaningful only in terms of some higher non-political end. The principle of limited government articulated, for instance, limits the legitimate domain of politics to securing the private freedoms of the governed, especially their right to property. In contrast, Arendt views freedom as an inherently political good since it can only be enjoyed in concert with others. If freedom is a public-political good, then politics has intrinsic value and does not require any further justification. But Arendt does not understand freedom exclusively in traditional republican terms as political autonomy (or selflegislation). Rather, she views freedom in terms of spontaneous action or natality, which 'marks the start of something, begins

\footnotetext{
${ }^{9}$ In relation to this point, Arendt's own ethnocentric prejudice about the lack of politics among 'vegetating' indigenous people in Australia and elsewhere is embarrassing and distressing. Notwithstanding this failure of political imagination on her own part, however, her characterisation of the political as disclosure of a common world seems to me to provide a valuable basis for understanding politics in non-European cultures and, indeed, between different cultures.
} 
something new, seizes the initiative, or, in Kantian terms, forges its own claim' (113).

The third prejudice that obscures our understanding of politics is that the ultimate means of politics is force and that it always ultimately concerns 'a relationship between the rulers and ruled' (97). In contrast, Arendt views all forms of instrumental or strategic action (according to which we exercise power in the sense of getting someone to do what they might otherwise would not do) as antipolitical. For the Greeks, such a relation was appropriate within the household (between master and slave or father and children) or in foreign affairs (between warring cities) but it was not appropriate for political life. Indeed, politics was only possible between citizens who were equal not just before the law (as in liberalism) but who were equally entitled to speak and inter-act with each other. Only where one had the opportunity to appear in public before one's equals was it possible to actualise freedom.

According to Arendt, then, politics is public. It is possible only where there is a public space within which men and women can appear before each other. Politics is also free. It is only by acting and speaking together politically that men and women actualise their freedom to initiate something new. Moreover, politics is intersubjective. Only when men and women are equally free to interact with each other can an inter-subjective reality be constituted from the plurality of perspectives that each individual brings to bear on the world that they share in common. If politics arises out of the plurality of perspectives that individuals bring to bear on the world, the political refers to the disclosure of this world as common to them.

From an ethical point of view, Arendt's conception of the political provides a preferable starting point for a theory of radical democracy than the Schmittian distinction between friend and 
enemy. Arendt's intention in appropriating the classical understanding of politics for modernity is to provide a source of hope in human affairs against the political catastrophes of the twentieth century. In presupposing plurality as the enabling condition for politics, it provides a basis from which to understand power and identity as an emergent property of collective action. Yet that is not to say that the Schmittian conception of the political is not conceptually correct in its claim that the possibility of political community is predicated on an act of exclusion that always entails a certain violence.

As Keith Breen (forthcoming) argues, Arendt ends up inverting the realist conception of the political in characterising violence as anti-political. While Arendt allows that violence and rule over others are sometimes justified in struggles for liberation and the founding of a space for politics, these phenomena are taken to be peripheral to politics and not political in themselves. This has the perverse effect of depoliticising relations of exclusion and oppression as merely 'social' issues rather than being properly political. Yet, as Michael Walzer emphasises, the struggle against unjust social relations is the substance of radical politics.

If the problem with appropriating a Schmittian conception of the political for a theory of radical democracy is how to employ it in a way constitutive of plurality, then, the problem with appropriating an Arendtian conception of the political is how to employ it in a way that politicises social inequality. This, arguably, is precisely what Sheldon Wolin $(1990 ; 1996)$ does by distinguishing between politics and the political where Arendt fails to. For Wolin (1996: 31) the political refers to the 'idea that a free society composed of diversities can nonetheless enjoy moments of commonality when, through public deliberations, power is used to promote or protect the well-being of the collectivity'. In contrast, politics refers to 'the 
legitimised and public contestation, primarily by organised and unequal social powers, over access to the resources available to the public authorities of the collectivity'. Against Arendt's reduction of all purposive action to the anti-political mentality of fabrication, this distinction allows Walzer's list of non-deliberative activities directed against social inequality to be recognised as politics (what else could they be?). Moreover it reserves the concept of 'the political' to be employed in the ethical sense developed by Arendt: as referring to the principle of freedom in terms of which political struggle is might come to be understood by the parties to a conflict as communal.

\section{Agonism as sublimation of antagonism}

The virtue of Walzer's account of non-deliberative politics is that it lends substance to debates about agonism in political theory, which are often highly abstract. We are now in a position to understand these activities as the stuff of ordinary politics, which is transacted against the background of 'the political'. But does this distinction provide a basis to radicalize Walzer's critique of dialogical liberalism as promised earlier? Mouffe would agree with Walzer that 'competition for power is the primary form of political life' and that passions are politically important for motivating people to act (128). Moreover, Mouffe agrees with Walzer that dialogical liberalism's misdescription of politics in terms of an ideal dialogue means that it tends to depoliticise and thereby make less visible social inequality.

Yet Mouffe goes further than Walzer in arguing that dialogical liberalism not only misdescribes political reality but actually exacerbates antagonistic social tendencies by denying those deemed unreasonable a legitimate avenue for the expression of their grievances. Rather than leading to the reconciliation of social 
conflict, the privileging of consensus depoliticises the terms within which politics is actually enacted. In particular, rather than understanding political conflict in terms of the drawing of constituencies according to the political distinction of friend and enemy, political conflict is represented in moral terms of right and wrong. This contributes to increasing resentment and hostility on the part of those whose perspectives are marginalised, excluded or assimilated by the hegemonic terms of political discourse. Following the logic of this argument, Mouffe attributes the rise of right-wing populist parties and the emergence of terrorism to the absence of 'legitimate political channels for the expression of grievances' within the existing neo-liberal consensus $(81,71)$.

Rather than representing political conflict in terms of an anticipated consensus among rational participants to a dialogue, Mouffe argues that the task for democratic theorists is to envisage 'a vibrant agonistic public sphere of contestation where different hegemonic political projects can be confronted' (p. 3). The risk of political conflict leading to violent confrontation is mitigated by reference to a symbolic context in which parties to a conflict can understand their confrontation as an 'agonistic' one between adversaries who respect each other rather than an 'antagonistic' one between enemies who mutually negate each other's form of life.

Mouffe understands agonism to be distinct both from selfinterested negotiation based on aggregating individual preferences and from rational deliberation oriented to consensus. While the former reduces politics to economics the latter reduces it to ethics. In contrast agonistic adversaries view their conflict as concerning the symbolic unity in terms of which their particular interests are represented and their contending claims are revealed to be 
irreconcilable (Mouffe 2005: 21). (Gesturing to Rawls, we might think of this symbolic unity as an 'overlapping dissensus').

According to Mouffe (2005: 21) radical democracy therefore requires the 'establishment of institutions and practices through which the potential antagonism can be played out in an agonistic way'. Rather than seeking to eliminate the political by subordinating it to economic or ethical categories, an agonistic approach would 'sublimate' it such that potential social antagonisms are 'played out under conditions regulated by a set of democratic procedures accepted by the adversaries' (21). Antagonistic conflicts are less likely to emerge where there are legitimate political channels through which dissenting voices can find expression.

Mouffe's commitment to radical democracy means that the conditions that ought to regulate an agonistic democratic politics can only be worked out politically and not specified in advance by a political theorist. However, she does identify one telling condition: conflict needs to 'take a form that does not destroy the political association' (20 - see also120). Yet surely the kinds of agonistic conflict that Mouffe wants to make a place for in democratic politics are precisely those that fundamentally challenge the terms of political association and are therefore likely to be perceived as a threat to democracy in a situation where the meaning of democracy is itself essentially contested. Indeed, survival, stability and/or security of the political association are the values most often invoked in a situation in which the defenders of an ostensibly democratic regime want to suppress their political opponents.

Moreover, it is questionable whether legitimating political grievances by providing greater scope for their expression serves to sublimate rather than intensify antagonism (e.g. Dryzek 2005: 220f.). Despite her awareness of the risk of politics intensifying toward violence, Mouffe seems to take for granted the 'integrative 
role that conflict plays in modern democracy' (p.31). Yet Mouffe's presumption that conflict will necessarily have an integrative function within a democratic polity is as unwarranted as her presumption that every political identity is necessarily formed in opposition to an antagonist. Indeed, everything depends precisely on whether participants view their conflict as communal ('agonism') or non-communal ('antagonism').

Mouffe's supposition that effective democratic institutions would do the work of representing the conflict as communal begs the question since, as Mouffe herself demonstrates so clearly, some consensus is needed about the basic norms that should be institutionalised in the first place (2005: 31, 52). Mouffe distinguishes her agonistic approach from dialogical liberalism on the grounds that consensus over institutional forms and procedures is grounded on the fundamental democratic value of liberty and equality for all, yet the meaning and implementation of these core values remains subject to disagreement. If that is the case, then these same democratic procedures can hardly be relied on to 'regulate' an agonistic conflict, which must fundamentally concern the procedures themselves.

Mouffe's agonism provides an important critical perspective from which to recognise the potentially ideological uses to which dialogical justifications of political regimes may be put insofar as they must represent political conflict as already communal. However, her theory lacks an adequate account of the institutionalization of agonistic democracy and, in particular, how this would be possible without domesticating agonistic politics. Having drawn attention to the potentially ideological function of ostensibly democratic institutions in regulating political conflict, Mouffe cannot then rely (as she sometimes does) on a shared commitment to these same institutions in order to sublimate a 
potentially antagonistic confrontation between enemies into an agonistic contest between adversaries.

\section{Agonism bound by law?}

Arendt's discussion of agonism is more indirect and ambivalent than Mouffe's, occurring as it does in the context of her discussion of the Greek conception of politics. In the Athenian polis, Arendt tells us, 'life consisted of an intense and uninterrupted contest of all against all' (16). On the one hand, Arendt describes approvingly the Greek's performative conception of action and their understanding of the polis as 'the public-political realm in which men attain their full humanity, their full reality as men' by appearing before each other (21). On the other hand, however, Arendt recognises that it was this agonal spirit of the Greeks that eventually brought their citystates to ruin. In this context, it is significant that she draws on Roman political experience to articulate a relational view of law that would mitigate the tendency of a 'hostile political encounter' to escalate into a war of annihilation (see Taminiaux 2000; Tsao 2003).

In Homer, the Greeks recognised that 'all things with two sides make their real appearance only in struggle' (166). The confrontation between Achilles and Hector, immortalised in The Illiad, exemplified the principle that it was only when confronted by an opponent and in the ensuing contest to be the best that individuals achieved excellence and disclosed who they were to the world. The achievement of the Athenians was to separate struggle from war and turn it into 'an integrating component of the polis and the political sphere' (172). Whereas the heroes of Homer's epics achieved greatness on the battlefield, the Athenians sought to create a space for politics in which such greatness might be revealed everyday in athletic competitions (which provided an 
opportunity for citizens to 'come together and admire a display of non-violent strength') and in oratorical contests (the 'never-ending verbal exchanges that took place within the polis itself') (166). In establishing a public space in which citizens could engage in argument about how the world appeared to them, this world was disclosed as common to them, first in its two-sidedness and then in terms of the plurality of perspectives that each individual brought to bear on it.

It is here that a decisive difference emerges between Mouffe's and Arendt's agonisim, which results directly from their different conceptions of the political. For Arendt, political agonism entails the clash between a plurality of perspectives that are brought to bear on the world by individuals. While plurality first makes its appearance in two-sidedness, however, a dichotomous view of the world is ultimately reductive of political reality; it is only where three or more perspectives come into play that genuine politics begins. As such, the Schmittian distinction between friend and enemy becomes anti-political to the extent that it prevents these other perspectives from emerging. ${ }^{10}$

Arendt's understanding of the political in terms of freedom thus enables her to recognise agonism as emerging out of the plurality based on the 'absolute difference of all men from one another, which is greater than the relative difference among peoples, nations, or races' (96). In contrast, Schmitt's understanding of the political in terms of exclusion means that agonism necessarily refers to a conflict between two opposing groups, which renders problematic from the outset Mouffe's ambition to employ it as a way of comprehending plurality within the polity. If consensus-oriented

\footnotetext{
${ }^{10}$ Arendt might have had Schmitt in mind, for instance, when she wrote in The Human Condition that when people are 'only for or against other people', the world-disclosing potential of action is curtailed; for then "speech becomes indeed "mere talk," simply one more means toward the end, whether it serves to deceive the enemy or to dazzle everybody with propaganda; here words reveal nothing' (Arendt 1998: 180).
} 
dialogue is always suspected of being ideological, then how might conflict be democratically sublimated so that it comes to be understood as common to the opposing groups, a relation of agonism rather than antagonism? Surely it is only with the emergence of further perspectives that the representation of a conflict as an incommensurable one between two competing forms of life can be recast in ways that might enable political antagonists to understand themselves otherwise.

Yet Arendt recognises that even the highly individualistic agonism of the Greeks, which she cautiously endorses, is risky since it constantly threatens the political association. Indeed, the agonal spirit of the Greeks eventually brought their city-states to ruin since 'it made alliances between them well-nigh impossible and poisoned the domestic life of the citizens with envy and mutual hatred' (16). The inadequacy of the Greek conception of politics was that the commonality of the political association was 'constituted only by the walls of the city and boundaries of its laws' rather than being experienced in terms of the web of human relationships that is revealed from a plurality of perspectives (16). While agonism is important for disclosing plurality, enabling the world to be perceived from its many sides, Arendt also recommends an ethic of care for this web of human relationships that emerges out of political interaction (see Canovan 1997; Schaap 2005, ch.4).

The promise of politics, as we have already seen is 'the political': the actualisation of freedom, the disclosure of commonness out of plurality. However, the capacity to begin anew, to set in train events over which we do not have control also threatens to tear the world apart. Politics, therefore, also stands in need of redemption by the human ability to forgive and to make promises. Significantly, however, these faculties were not recognised by the Greeks but appear rather in two principles of 
Roman 'foreign policy': namely, of sparing the vanquished and making treaties with their former enemies (178).

Arendt draws out this key difference between the Greeks and the Romans in terms of their contrasting conceptions of law. Whereas, for the Greeks, law enabled politics by establishing a space within which citizens were free and equal, law itself was not political but rather pre-political; it was made rather than enacted. As such, the founding law of the polity might be drafted by a foreigner just as an architect might be commissioned to design the city walls (179). While the Greeks understood that law was a necessary precondition for politics, since it served to delimit the space in which citizens could actualise their freedom, they viewed it as anti-political because they understood it as command.

For the Romans, in contrast, the founding of public law was the most fundamental of all political acts. Indeed, Rome's own founding law was not the work of one man but 'a contract between two warring factions, the patricians and the plebes, that required the approval of the entire populace' (179). The law did not unite the Romans by erasing the difference between them but rather established a lasting tie between them in the form of a contract. By viewing law in relational terms of promising the Romans were able to formulate a properly political concept of law as the 'institution of a relationship between conflictual sides of a pluralistic interaction' (Taminiaux 2000, 176).

For the Romans, the natural pursuit of every war is a treaty or alliance rather than the destruction of one's enemy. As such every peace treaty 'is concerned with a new ordering of things as they existed before the outbreak of hostilities but also of the new thing that made its appearance in the course of hostilities and is shared by both doers and sufferers' (177). As such, Arendt argues, the 
Romans discovered politics 'at the very place where it had reached its limits and come to an end among the Greeks' (178).

Whereas for the Greeks, politics was possible only among citizens of equal rank within the city walls, for the Romans politics grew 'between alien and unequally matched people who first came together in battle' (178). While the political existence of the Greeks was founded in struggle and war, this came about in the Schmittian way: they came to identify themselves as a "we" in opposition to a shared enemy and then 'came together to preserve their own nature' (178). For the Romans, in contrast, 'this same struggle became the means by which they recognised both themselves and their opponents' (178). By making a treaty with their enemies rather than annihilating them, the Romans expanded political space so that a new world could arise between the two peoples brought together by war. A treaty could guarantee the continuation of a new world that they share in common, which arose out of their meeting in battle, where deeds and suffering brought forth one and the same thing' (178).

As with Arendt's distinction between the 'good' American and 'bad' French revolutions, there seems to be something ideological at work in her contrast between the Greek and Roman conceptions of law and foreign policy. ${ }^{11}$ In particular, Arendt elides the extent to which Roman treaty-making was imperialistic and backed by the threat of total destruction. As with her work on revolution, what is most interesting in Arendt, however, is the ambiguity in her endorsement of the Greek and Roman conceptions of law as command and relation, respectively. While ostensibly affirming the Roman conception against the Greek, the dichotomy she constructs

\footnotetext{
${ }^{11}$ For instance she passes lightly over the annihilation of Carthage by the Romans, which they understood to be justified because Carthage posed a mortal threat to Rome. As Keith Breen points out (personal correspondence 8 February 2006), this suggests that the Romans' distinguished between different categories of enemies: in Mouffe's terms those who could become adversaries united by law and those who would remain antagonists to be destroyed.
} 
breaks down elsewhere in her work so that law appears more ambiguously as both command and relation. As such, the space for freedom that law delimits is founded both in the promise of inclusion and an act of violent appropriation, as both 'giving' and 'taking' as Hans Lindahl (forthcoming) puts it.

The agonistic critique of dialogical liberalism is unavoidably transient because it understands democracy not in institutional terms but as an ethos that affirms indeterminacy, the openness of political life and the never-ending play of the agon. This ethos arises from agonists' central concern with the possibility of genuine political action: that which is not already over-determined by its institutional representation, with natality (in Arendt's terms) or constituent power (in Schmitt's). This agonistic ethos is important to the extent that it draws attention to what is excluded and occluded in the representation of legitimate politics as dialogue. As ethos, however, an agonistic theory of democracy does not amount to an alternative 'model' of democracy as Mouffe sometimes seems to suggest.

On the one hand, to require it to do so would already be to represent it in liberalism's own terms such that the most it could amount to would be a 'correction' of a hegemonic discourse. On the other hand, however, without an adequate conceptualization of the implication of an agonistic politics for democratic institutions, agonistic theories of democracy can be too easily dismissed as failing to offer a real alternative to dialogical liberalism. While Arendt by no means develops a full-blown theory of democratic institutions, her intriguing discussion of the Greek and Roman conceptions of law in The Promise of Politics might provide a 
valuable starting point from which theorists of agonistic politics might begin to do so. ${ }^{12}$

\section{References}

Benhabib, Seyla (1996) The Reluctant Modernism of Hannah Arendt. London: Sage Publications.

Brady, John S. (2004) 'No contest? Assessing the agonistic critiques of Jürgen Habermas's theory of the public sphere', Philosophy and Social Criticism 30(3): 331-354.

Breen, Keith (forthcoming) 'Violence and Power: A Critique of Hannah Arendt on 'the Political", Philosophy and Social Criticism.

Cannovan, Margaret (1997) 'Hannah Arendt as a conservative thinker' in Larry May and Jerome Kohn (eds) Hannah Arendt: Twenty Years Later. Cambridge, MA: MIT Press.

Christodoulidis, Emilios (1998) Law and Reflexive Politics. Dordrecht: Kluwer Academic Publishers.

Christodoulidis, Emilios (2006) 'Republican Constitutionalism and Reflexive Politics', Archives for Philosophy of Law and Social Philosophy 92(1): 1-14.

d'Entrèves, Maurizio Passerin (1994) The Political Philosophy of Hannah Arendt. London: Routledge.

Dryzek, John (2005) 'Deliberative Democracy in Divided Societies: Alternatives to Agonism and Analgesia', Political Theory 33(2): 218-242.

Hampshire, Stewart (2000) Justice is Conflict. Princeton: Princeton University Press.

Honig, Bonnie (1993) Political Theory and the Displacement of Politics.

Kalyvas, Andreas (2000) 'Carl Schmitt and the Three Moments of Democracy', Cardozo Law Review 21: 1525-1565.

Kymlicka, Will (1989) Liberalism, Community and Culture. New York: Oxford University Press.

Lefort, Claude (1988) 'Hannah Arendt and the Question of the Political' in Democracy and Political Theory. Cambridge: Polity.

\footnotetext{
${ }^{12}$ For an insightful development of an Arendtian conception of law in this direction see Lindahl (forthcoming).
} 
Lindahl, Hans (forthcoming) 'Give and Take: Arendt and the Nomos of Political Community', Philosophy and Social Criticism.

Little, Adrian (2004) 'Liberalism, democracy and the politics of disagreement', paper presented at the Australasian Political Studies Association Conference, University of Adelaide, 1 October.

Mouffe, Chantal (1993) The Return of the Political. London: Verso.

Rancière, Jacques (1999) Disagreement: Politics and Philosophy, trans. Julie Rose. Minneapolis: University of Minnesota Press.

Rancière, Jacques (2001) 'Ten Theses on Politics', Theory and Event $5(3)$.

Rawls, John (1993) Political Liberalism. New York: Columbia University Press.

Schaap, Andrew (2005) Political Reconciliation. London: Routledge.

Schmitt, Carl (1996) The Concept of the Political, trans. George Schwab. Chicago: University of Chicago Press.

Shiffman, Gary (2002) 'Construing Agreement: Consensus and Invective in "Constitutional" Debate', Political Theory 30(2): 175-203.

Sunstein, Cass (2003) Why Societies Need Dissent. London: Harvard University Press.

Taminiaux, Jacques (2000) 'Athens and Rome' in Dana Villa (ed.) The Cambridge Companion to Hannah Arendt. Cambridge: Cambridge University Press.

Tsao, Roy T. (2002) 'Arendt Against Athens: Rereading the Human Condition', Political Theory 30(1): 97-123.

Villa, Dana (1996) Arendt and Heidegger: The Fate of the Political. Princeton: Princeton University Press.

Walzer, Michael (1973) 'Political Action: the Problem of Dirty Hands', Philosophy and Public Affairs 2: 160-180.

Walzer, Michael (1981) 'Democracy and Philosophy', Political Theory 9: $379-400$.

Walzer, Michael (1990) 'The Communitarian Critique of Liberalism', Political Theory 18(1): 6-23.

Wolin, Sheldon (1990) 'Hannah Arendt: Democracy and the Political' in Reuben Garner (ed.) The Realm of Humanitas: responses to the writings of Hannah Arendt. New York: Lang.

Wolin, Sheldon (1996) 'Fugitive Democracy' in Seyla Benhabib (ed.) Democracy and Difference: Contesting the Boundaries of the Political. Princeton: Princeton University Press. 


\section{University Library}

\section{- M M I N E R VA A gateway to Melbourne's research publications}

Minerva Access is the Institutional Repository of The University of Melbourne

Author/s:

Schaap, A

Title:

Political theory and the agony of politics

Date:

2007-01-01

Citation:

Schaap, A. (2007). Political theory and the agony of politics. Political Studies Review, 5 (1), pp.56-74. https://doi.org/10.1111/j.1478-9299.2007.00123.x.

Publication Status:

Published

Persistent Link:

http://hdl.handle.net/11343/33393 